\title{
Viable Bacterial Load Is Key to Azithromycin Treatment Failure in Rectally Chlamydia trachomatis Infected Women (FemCure)
}

Citation for published version (APA):

Dukers-Muijrers, N. H. T. M., Wolffs, P. F. G., de Vries, H. J. C., Gotz, H. M., Janssen, K., \& Hoebe, C. J. P. A. (2019). Viable Bacterial Load Is Key to Azithromycin Treatment Failure in Rectally Chlamydia trachomatis Infected Women (FemCure). Journal of Infectious Diseases, 220(8), 1389-1390.

https://doi.org/10.1093/infdis/jiz267

Document status and date:

Published: 15/10/2019

DOI:

10.1093/infdis/jiz267

Document Version:

Publisher's PDF, also known as Version of record

Document license:

Taverne

Please check the document version of this publication:

- A submitted manuscript is the version of the article upon submission and before peer-review. There can be important differences between the submitted version and the official published version of record.

People interested in the research are advised to contact the author for the final version of the publication, or visit the DOI to the publisher's website.

- The final author version and the galley proof are versions of the publication after peer review.

- The final published version features the final layout of the paper including the volume, issue and page numbers.

Link to publication

\footnotetext{
General rights rights.

- You may freely distribute the URL identifying the publication in the public portal. please follow below link for the End User Agreement:

www.umlib.nl/taverne-license

Take down policy

If you believe that this document breaches copyright please contact us at:

repository@maastrichtuniversity.nl

providing details and we will investigate your claim.
}

Copyright and moral rights for the publications made accessible in the public portal are retained by the authors and/or other copyright owners and it is a condition of accessing publications that users recognise and abide by the legal requirements associated with these

- Users may download and print one copy of any publication from the public portal for the purpose of private study or research.

- You may not further distribute the material or use it for any profit-making activity or commercial gain

If the publication is distributed under the terms of Article $25 \mathrm{fa}$ of the Dutch Copyright Act, indicated by the "Taverne" license above, 


\section{Viable Bacterial Load Is Key to Azithromycin Treatment Failure in Rectally Chlamydia trachomatis Infected Women (FemCure)}

To THE EDITOR-With great interest we read the article by Khosropour et al [1], in which the health implications of rectal Chlamydia trachomatis in women was studied by daily sampling of rectal and vaginal specimens. Undetected or inappropriately treated rectal C. trachomatis could have consequences both for the patient and sexual partners via ongoing transmission. Khosropour et al [1] conclude that rectal C. trachomatis infections are common in women, and anticipate that azithromycin treatment might fail in the case of rectal C. trachomatis. As acknowledged, their sample size ( $\mathrm{n}=13$ ) was too small to observe rectal C. trachomatis treatment failure.

We recently described treatment effectiveness of azithromycin and doxycycline in women with rectal or vaginal C. trachomatis infections using nucleic acid amplification testing (NAAT) at week 4 [2]. As rightfully noted by Khosropour et al [1], NAAT cannot distinguish DNA derived from viable $C$. trachomatis or nonviable $C$. trachomatis remnants. Frequently observed posttreatment blips, that is C. trachomatis positivity after initial clearance, are also notable in this respect with unknown meaning for viability. In the current postculture era, where C. trachomatis is routinely diagnosed using NAAT, we developed a viability polymerase chain reaction assay (V-PCR) to assess viability of $C$. trachomatis with higher sensitivity than culture [3].

In our FemCure study, we applied viability testing to assess treatment failure in 112 women who were rectal and vaginal NAAT-C. trachomatis-positive, and who, in the 4 weeks posttreatment, did not use antibiotics, nor vomited, and denied rectal and vaginal unprotected sex. Just prior to treatment and at 4 weeks after azithromycin treatment (1 g single dose), participants self-collected vaginal and rectal samples, and tested for
C. trachomatis DNA (NAAT) and viable C. trachomatis (V-PCR). Based on the week 4 samples, we evaluated 2 endpoints: (1) failure per C. trachomatis DNA and (2) failure per viable C. trachomatis.

Regarding failure per $C$. trachomatis DNA at week 4, 19 (17.0\%) of the 112 women had $C$. trachomatis DNA at the rectal site only, 3 (2.7\%) had C. trachomatis DNA at the vaginal site only, and 5 (4.5\%) had C. trachomatis DNA at both anatomic sites (Table 1). Regarding failure per viable C. trachomatis, 17 (15.2\%) had viable C. trachomatis at the rectal site only, 2 (1.8\%) had viable $C$. trachomatis at the vaginal site only, and 1 (0.9\%) had viable C. trachomatis at both the rectal and vaginal sites.

A few notable observations arise when we also consider the presence (or absence) of viable $C$. trachomatis just prior to treatment.

1. Just prior to treatment, almost all participants had viable $C$. trachomatis at the vaginal site $(96 \%, 108 / 112)$ and a substantial number $(58 \%, 65 / 112)$ had viable $C$. trachomatis at the rectal site.

2. As we observed previously for C. trachomatis DNA [2], viable C. trachomatis at week 4 was more frequently observed at the rectal site (16.1\%) than at the vaginal site $(2.7 \%)$.

3. Pretreatment viable $C$. trachomatis at the rectal site (or the absence thereof) affected the later occurrence of failure per viable C. trachomatis; failure was $25.4 \%$ in women with pretreatment viable C. trachomatis and $4.4 \%$ in women without pretreatment viable C. trachomatis (Table 1). We could not evaluate the impact of pretreatment viable C. trachomatis at the vaginal site as only 4 women did not have viable C. trachomatis at the vaginal site.

We also explored the impact of "blips" by assessing $C$. trachomatis DNA at week 1 and 2 . We considered women with C. trachomatis DNA at the rectal site at week $4(\mathrm{n}=24)$ as failures with blips when women did not have C. trachomatis DNA at week 1 or week $2(\mathrm{n}=10)$. Of the failures with blips, $8(57.1 \%)$ had viable C. trachomatis at the rectal site at week 4 ; of the failures ( $\mathrm{n}=14$ ) without blips, all had viable C. trachomatis at week 4. As Khosropour et al [1] concluded, the cause of rectal C. trachomatis blips is unclear, but may be a result of persistent infection, reinfection via autoinoculation, or persistence of nonviable organisms. We add that possible clinical relevance of blips should not be ruled out, as in our study over half of the failures with blips showed viable $C$. trachomatis.

Given the frequent cooccurrence of rectal C. trachomatis with vaginal C. trachomatis, it is possible that providing azithromycin to women with vaginal $C$. trachomatis and unnoticed rectal C. trachomatis infections, may result in rectal $C$. trachomatis treatment failure. The current observations suggest that rectal treatment failure may reflect viable C. trachomatis, likely depending on the presence of viable $C$. trachomatis prior to treatment.

We hope that our presented results emphasize the importance of rectal C. trachomatis infections in women. Appropriate diagnostics and treatment are of importance both for the patient to prevent late sequalae and for society to prevent ongoing transmission.

\section{Notes}

Ethics statement. All participants provided written informed consent. This study was approved by the Medical Ethical Review Committee from the Maastricht University Medical Centre (NL51358.068.15/METC153020, 20-012016) and was monitored by the Clinical Trial Centre, Maastricht University.

\section{Clinical Trials Registration.} NCT02694497.

Disclaimer. The funding source had no role in the writing or publication of this letter.

Financial support. This work was supported by the Netherlands Organization for Health Research and Development (grant number 50-53000-98-109). 


\begin{tabular}{|c|c|c|c|c|}
\hline \multirow[b]{2}{*}{ Test Result Prior to Treatment } & \multicolumn{2}{|c|}{ Rectal Chlamydia at Week 4, n (\%) } & \multicolumn{2}{|c|}{ Vaginal Chlamydia at Week 4, n (\%) } \\
\hline & NAAT Positive & V-PCR Positive & NAAT Positive & V-PCR Positive \\
\hline Chlamydia DNA at vaginal and rectal site, $n=112$ & $24(21.4)$ & $18(16.1)$ & $8(7.1)$ & $3(2.7)$ \\
\hline \multicolumn{5}{|l|}{ Viable Chlamydia } \\
\hline No viable Chlamydia at vaginal and rectal site, $n=2$ & 0 & 0 & 0 & 0 \\
\hline No viable Chlamydia at vaginal site, viable Chlamydia at rectal site, $\mathrm{n}=2$ & 0 & 0 & 0 & 0 \\
\hline Viable Chlamydia at vaginal site, no viable Chlamydia at rectal site, $n=45$ & $5(11.1)$ & $2(4.4)$ & $2(4.4)$ & $1(2.2)$ \\
\hline Viable Chlamydia at vaginal and rectal site, $n=63$ & $19(30.2)^{*}$ & $16(25.4)^{*}$ & $6(9.5)$ & $2(3.2)$ \\
\hline \multicolumn{5}{|c|}{$\begin{array}{l}\text { Treatment failure was defined as NAAT positive at week } 4 \text { or V-PCR positive at week } 4 \text { in rectal and vaginal infections, in } 112 \text { women who were vaginal and rectal NAAT positive just prior to } \\
\text { treatment, FemCure, the Netherlands 2016-2017. }\end{array}$} \\
\hline \multicolumn{5}{|c|}{ NAAT positive indicates presence of Chlamydia DNA; V-PCR positive indicates presence of viable Chlamydia. } \\
\hline Abbreviations: NAAT, nucleic acid amplification testing; $V-P C R$, viability polymerase chain & & & & \\
\hline
\end{tabular}

Potential conflicts of interest. All authors: No reported conflicts of interest. All authors have submitted the ICMJE Form for Disclosure of Potential Conflicts of Interest. Conflicts that the editors consider relevant to the content of the manuscript have been disclosed.

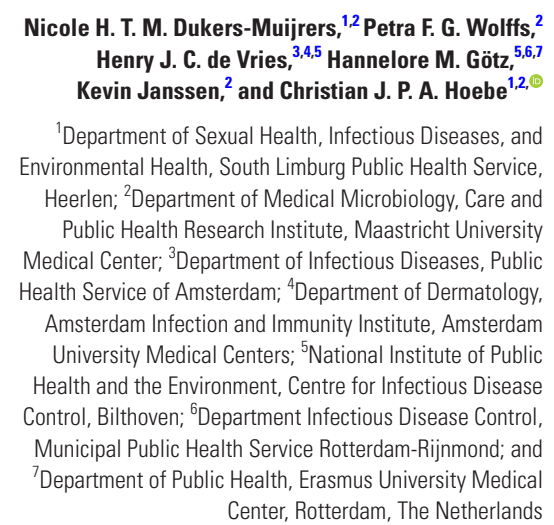

\section{References}

1. Khosropour CM, Soge OO, Suchland R, et al. Recurrent/intermittent vaginal and rectal chlamydial infection following treatment: a prospective cohort study among female STD clinic patients [published online ahead of print 12 March, 2019]. J Infect Dis doi: 10.1093/infdis/jiz113.

2. Dukers-Muijrers NHTM, Wolffs PFG, Vries H, et al. Treatment effectiveness of azithromycin and doxycycline in uncomplicated rectal and vaginal Chlamydia trachomatis infections in women: a multicentre observational study (FemCure) [published online ahead of print 28 January, 2019]. Clin Infect Dis doi: 10.1093/cid/ciz050.

3. Janssen KJH, Dirks JAMC, DukersMuijrers NHTM, Hoebe CJPA, Wolffs PFG. Review of Chlamydia trachomatis viability methods: assessing the clinical diagnostic impact of NAAT positive results. Expert Rev Mol Diagn 2018; 18:739-47.

Received 6 April 2019; accepted 18 May 2019; published online May 20, 2019.

Correspondence: Nicole H. T. M. Dukers-Muijrers, PhD, Public Health Service South Limburg, Department of Sexual Health, Infectious Diseases and Environmental Health, PO Box 33, 6400 AA Heerlen, The Netherlands (Nicole.dukers@ ggdzl.nl).

The Journal of Infectious Diseases ${ }^{\circledR} \quad$ 2019;220:1389-90 (C) The Author(s) 2019. Published by Oxford University Press for the Infectious Diseases Society of America. All rights reserved. For permissions, e-mail: journals.permissions@oup.com. DOl: 10.1093/infdis/jiz267

\section{Reply to Dukers-Muijrers et al}

To THE EDITOR-Dukers-Muijrers et al provide new data that are complementary to those from our study [1]. Namely, they found that over one quarter of women who had viable Chlamydia trachomatis detected in the rectum before receiving azithromycin treatment also had viable $C$. trachomatis detected 4 weeks after treatment, suggesting possible treatment failures. They also note that over half of women with intermittent C. trachomatis-positive results (or "blips") of rectal specimen tests showed evidence of viable C. trachomatis.
Together, the data from our study and those from Dukers-Muijrers et al add key pieces to the puzzle of the clinical significance of rectal C. trachomatis among women. We now have data to demonstrate that, among women, (1) rectal C. trachomatis is prevalent, commonly cooccurs with vaginal $C$. trachomatis, and is not associated with reporting anal sex [2]; (2) detection of rectal C. trachomatis via nucleic acid amplification testing likely represents the presence of viable bacteria in the rectum; and (3) failure of azithromycin treatment for rectal C. trachomatis occurs somewhat frequently. Together, these findings suggest that limiting rectal screening to women who only report anal sex will miss a substantial number of cases but that providing azithromycin treatment to women with vaginal $C$. trachomatis without regard to whether they have concurrent rectal C. trachomatis could result in persistent rectal C. trachomatis.

Thus, the following question remainswhat additional evidence is needed to recommend routine screening for rectal infections among women? Arguably, the strongest evidence would demonstrate that these infections lead to adverse health outcomes. As we have previously noted [1], data from animal models suggest that autoinfection from the rectum to the vagina occurs [3-5], which could lead to ongoing transmission and reproductive tract morbidity. But the extent to which autoinfection occurs in humans is still unclear, and the most appropriate 